\title{
AKTIVITAS HEMOLITIK TERIPANG (Bohadschia graeffei) DARI PANTAI MALALAYANG, SULAWESI UTARA PADA BEBERAPA SUHU DAN pH
}

\author{
Remy E.P. Mangindaan ${ }^{1)}$, Fitje Losung ${ }^{1)}$ \\ 1) Fakultas Perikanan dan Ilmu Kelautan, Universitas Sam Ratulangi \\ Jl. Kampus Unsrat, Manado 95115 \\ email: remysang@yahoo.com; vera.losung@yahoo.com
}

\begin{abstract}
ABSTRAK
Teripang (Bohadschia graeffei) merupakan salah satu sumber bahan hayati laut yang bermanfaat di bidang pangan maupun biomedik. Hewan ini dilaporkan memiliki kandungan hemolisin, yaitu protein aktif yang mampu melisis sel darah merah. Pengembangan potensi hemolitiknya dapat menjadikannya sebagai kandidat obat antitumor, sitolisin ataupun bahan dalam bidang kajian biomedik. Namun demikian, hingga saat ini, belum banyak penelitian mengenai hemolisin teripang yang berasal dari perairan Sulawesi Utara. Sampel teripang yang diperoleh diekstraksi mengikuti metode Kamiya et al. (1991) yang telah dimodifikasi. Sampel teripang segar diblender dan dilarutkan dalam larutan Buffer fosfat. Setelah diaduk, campuran disaring dan filtrat yang diperoleh disentrifus. Pada supernatan, kemudian dilakukan proses salting out dengan penambahan amonium sulfat. Proses ini dibantu dengan penambahan aseton. Ekstrak kasar yang diperoleh dikeringkan untuk digunakan dalam uji aktivitas hemolitik dengan menggunakan suspensi eritrosit standar. Unit Hemolitik (HU). Hasil pengujian menampakkan bahwa aktivitas hemolitik teripang terjadi pada suhu dan $\mathrm{pH}$ optimum berturut-turut yaitu $50{ }^{\circ} \mathrm{C}$ dan 8 . Nampak bahwa suhu optimum cukup tinggi dan tidak terjadi penurunan aktivitas yang tajam pada suhu yang lebih tinggi. Hal ini merupakan suatu hal yang unik dan masih harus diteliti lebih lanjut.
\end{abstract}

Kata kunci : $\quad$ aktivitas hemolitik, Bohadschia graeffei, hemolisin, pantai Malalayang

\section{HEMOLYSIN ACTIVITY OF SEA CUCUMBERS (Bohadschia graffei) FROM MALALAYANG COASTAL, NORTH SULAWESI ON DIFFERENT TEMPERATURES AND pH}

\begin{abstract}
Sea cucumber (Bohadschia graeffei) is one of marine resource that useful in food and biomedical fields. This animal contains hemolysin; a protein is able to lysis red blood cells. Developing of its potential hemolytic activity can make this animal to be a candidate of antitumor drug, sitolisin or material in biomedical researxh. However, until now, only a little information has been found about hemolysin from sea cucumbers from seas in North Sulawesi. Sea cucumbers samples were extracted following the modified method of Kamiya et al. (1991). Samples of fresh cucumber were blended and dissolved in phosphate buffer solution. After stirring, the mixture was filtered and the obtained filtrate was centrifused. Then, supernatant were processed salting out with adding ammonium sulfate. This process was aided by adding acetone. Crude extract obtained was dried to be used in hemolytic activity assay by using standard erythrocyte suspension. Test results showed that the hemolytic activity of sea cucumbers occured at optimum temperature and $\mathrm{pH}$ was respectively $50{ }^{\circ} \mathrm{C}$ and 8 . It appears that the optimum temperature is high enough and not sharp decline in activity at higher temperatures. This is a unique thing and needed to be investigated further.
\end{abstract}

Keywords: hemolytic aktivity, Bohadschia graeffei, hemolysin, Malalayang coastal

\section{PENDAHULUAN}

Keanekaragaman hayati laut dapat dimanfaatkan untuk berbagai keperluan, di antaranya keperluan biomedik. Perairan laut
Sulawesi Utara dikenal sebagai kawasan yang memiliki keanekaragaman hayati yang tinggi, antara lain teripang. Tiensongrusmee \& Pontjoprawiro (1988) menyatakan 
perairan Sulawesi Utara merupakan salah satu wilayah potensial bagi pengembangan budidaya teripang. Sebagai salah satu invertebrata laut, teripang dilaporkan mengandung senyawa protein aktif yang mampu melisis sel darah merah (eritrosit). Senyawa ini dikenal sebagai hemolisin, yang merupakan salah satu produk metabolit sekunder (Russell, 1965; Hashimoto, 1979; Shiomi et al., 1986; Kamiya et al., 1991).

Jenis teripang tertentu dapat mengeluarkan serabut getah dari dalam rongga tubuhnya yang bersifat toksik terhadap ikan, hewan laut lainnya dan pada manusia (Hashimoto 1979). Russell (1965) menyatakan bahwa beberapa spesies teripang memiliki sejumlah tubula yang berwarna putih, merah muda atau merah yang berfungsi sebagai organ-organ pertahanan khusus, yang disebut organ "cuvierian". Apabila organ ini teriritasi, tubula-tubula akan dikeluarkan melalui anus menyerupai benang yang sangat lengket dan dapat menjerat predator yang menyerangnya. Materi ini merupakan suatu massa protein tidak berbentuk dengan sifat pelekatan sangat kuat. Hashimoto (1979) menyatakan bahwa toksin yang dikandung teripang pada dasarnya adalah saponin triterpenoid yang merupakan komponen utama toksin pada Echinodermata.

$\mathrm{Tu}$ (1988) melaporkan, selain holothurin, jenis-jenis toksin lain yang dikandung teripang, yaitu bohadschiosida, stichoposida, thelenotosida dan holotoksin. Toksin teripang bersifat ichtiotoksik, hemolitik, sitotoksik, antifungi (Hashimoto, 1979), antiviral (Wright, 1984), antimetabolik, neurotoksik (Russell, 1965), dan antitumor (Florkin \& Scheer, 1969).

Hemolisis merupakan peristiwa luruhnya membran eritrosit yang mengakibatkan keluarnya isi sel diikuti lepasnya molekul hemoglobin yang terkandung di dalamnya. Boorman et al. (1988) menyatakan bahwa pada peristiwa lisis membran eritrosit tetap dalam keadaan tidak terurai, tetapi pada bagian membran tertentu terjadi kebocoran yang menyebabkan keluarnya isi sel karena mekanisma komplemen pada gabungan antigen-antibodi. Mekanisma hemolisin melisis sel darah merah dari beberapa bakteri yaitu dengan membentuk pori-pori pada membran sel (Chalneau et al., 2010).
Hemolisin, sebagai senyawa penyebab hemolisis, ditemukan pada beberapa biota laut misalnya anemon laut (Anthopleura japonica) (Shiomi et al., 1986), ular laut (Tugali gigas) dan teripang (Holothuria polii) (Kamiya et al., 1991), bakteri dan jamur (Humm \& Lane, 1974). Aktivitas hemolitik dapat diukur dengan menggunakan satuan hemolitik unit (HU). Satu hemolitik unit merupakan jumlah hemolisin yang dapat melisis setengah dari keseluruhan jumlah eritrosit pada suspensi eritrosit standar yang digunakan (Humm \& Lane, 1974).

Metabolit sekunder dari invertebrata laut dapat diekstraksi lanjut untuk dijadikan bahan baku obat (Wright, 1984; Humm \& Lane, 1974). Demikian pula, hemolisin pada teripang dapat dikembangkan potensinya sebagai sitolisin, kandidat obat antitumor ataupun bahan untuk bidang kajian biomedik. Di beberapa negara maju, jenis-jenis teripang tertentu selain dimanfaatkan sebagai bahan pangan, juga telah dimanfaatkan sebagai bahan baku dalam industri obat-obatan. Namun, di Sulawesi Utara pemanfaatan teripang belum terlalu berkembang dan informasi ilmiah mengenai hemolisin pada teripang belum tersedia. Penelitian ini bertujuan untuk mengukur suhu dan $\mathrm{pH}$ optimum bagi aktivitas hemolitik dari ekstrak hemolisin teripang (Bohadschia graeffei).

\section{METODE PENELITIAN}

\section{a. Tempat dan Waktu Penelitian}

Sampel teripang (B.graeffei) berasal dari Pantai Malalayang, Sulawesi Utara. Uji aktivitas hemolitik dilakukukan di Laboratorium Kimia Bahan Hayati Laut, Fakultas Perikanan dan Ilmu Kelautan, Universitas Sam Ratulangi - Manado. Penelitian dilaksanakan pada April 2012 hingga Juni 2012.

\section{b. Bahan dan Cara kerja}

\section{Pengambilan Sampel}

Pengambilan sampel B.graeffei dilakukan di daerah subtidal Pantai Malalayang. Sampel yang diperoleh lalu dibungkus secara terpisah dengan plastik pembungkus (cliploc) segera setelah 
pengambilan. Sampel kemudian dibawa ke laboratorium untuk diekstraksi.

\section{Ekstraksi Hemolisin}

Ekstraksi hemolisin mengikuti metode Kamiya et al. (1991) yang dimodifikasi. Sampel teripang digiling dengan blender hingga halus lalu diaduk dalam larutan $0,06 \mathrm{M}$ PB ( $\mathrm{pH} 7$ ) selama 24 jam pada suhu $5^{\circ} \mathrm{C}$ lalu disaring. Selanjutnya, filtrat disentrifus (3500 rpm; $60 \mathrm{~min}$ ) diikuti proses salting out dengan $50 \%$ amonium sulfat $\left(\mathrm{NH}_{4}\right)_{2} \mathrm{SO}_{4}$ dalam supernatan. Pengendapan ekstrak kasar dibantu dengan penambahan aseton. Ekstrak kasar dikeringkan dengan vakum evaporasi, ditimbang dan disimpan dan siap digunakan saat pengujian hemolisis.

\section{Penyiapan Eritrosit}

Darah manusia (golongan O) dari pendonor sebanyak $100 \mathrm{ml}$, yang telah disimpan di dalam kantung Terumo di lemari es, dimasukkan dalam tabung lalu disentrifus pada $3000 \mathrm{rpm}$ selama 3 menit. Selanjutnya, leukosit (buffy coat) dan plasma darah dikeluarkan. Larutan PBS pH 7 sebanyak dua kali volume ditambahkan pada presipitat eritrosit kemudian disentrifus kembali pada 3500 rpm selama 3 menit. Pencucian ini dilakukan tiga kali. Selanjutnya eritrosit disuspensikan kembali dalam PBS $(50 \quad x$ volume $)$ sehingga diperoleh suspensi eritrosit dengan kepadatan sel $2 \%$.

\section{Uji Aktivitas Hemolitik pada Beberapa Suhu}

Ekstrak kasar kering sebanyak 0,56 g dilarutkan dalam $100 \mathrm{ml} 0,06 \mathrm{M}$ PB pada $\mathrm{pH}$ 7. Lalu, sebanyak $1 \mathrm{ml}$ larutan ekstrak tersebut ditambahkan ke dalam 7 tabung yang masing-masing berisi $9 \mathrm{ml}$ larutan PB. Tabung-tabung ini lalu diinkubasi selama 30 menit, masing-masing pada suhu $25^{\circ} \mathrm{C}$, $30^{\circ} \mathrm{C}, 40^{\circ} \mathrm{C}, 50^{\circ} \mathrm{C}, 60^{\circ} \mathrm{C}, 70^{\circ} \mathrm{C}$, dan $80^{\circ} \mathrm{C}$. Setelah diinkubasi, tabung-tabung tersebut dikembalikan pada suhu ruang $\left(25^{\circ} \mathrm{C}\right)$ untuk uji aktivitas hemolitik. Selanjutnya, uji aktivitas hemolitik dilakukan dengan cara menambahkan $0,1 \mathrm{ml}$ larutan ekstrak ke dalam 2,9 ml suspensi eritrosit $2 \%$. Setelah campuran diaduk dengan vorteks, campuran diinkubasi selama 30 menit pada suhu ruang.
Campuran yang telah diinkubasi kembali diaduk dengan vorteks dan disentrifus pada kecepatan 3000 rpm selama 3 menit. Pengukuran nilai absorban supernatan dilakukan pada spektrofotometer pada panjang gelombang $540 \mathrm{~nm}$.

\section{Uji Aktivitas Hemolitik pada Beberapa pH}

Setiap tabung yang telah diisi

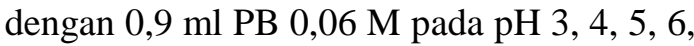
7, 8, 9 dan 10 ditambahkan $0,1 \mathrm{ml}$ larutan ekstrak dengan konsentrasi $56 u \mathrm{~g} / \mathrm{ml}$. Setelah diaduk dengan vorteks, larutan ekstrak diinkubasi selama 12 jam pada suhu $5^{\circ} \mathrm{C}$. Larutan ekstrak yang telah diberi perlakuan $\mathrm{pH}$ ini lalu diuji aktivitas hemolitiknya seperti pada pengujian untuk melihat pengaruh suhu, dengan menggunakan suspensi eritrosit $2 \%$ dalam 0,06 M PBS pada pH 7. Setiap larutan ekstrak yang telah diberi perlakuan suhu atau $\mathrm{pH}$ diuji aktivitas hemolitiknya dengan tiga kali pengulangan.

\section{HASIL DAN PEMBAHASAN}

Ekstraksi B.graeffei sebanyak 100 g berat basah menghasilkan filtrat sekitar $80 \mathrm{ml}$. Setelah salting out dan pengeringan diperoleh ekstrak kering hemolisin kasar berupa tepung berwarna kuning-kecoklatan sebanyak $1,17 \mathrm{~g}$ dengan aroma khas.

\section{Pengaruh Suhu}

Jumlah hemolisin yang menyebabkan $50 \%$ hemolisis pada eritrosit standar didapat dari rata-rata nilai absorbans sampel dibagi dengan nilai absorbans 50\% hemolisis pada kurva standar. Nilai aktivitas hemolitik, dinyatakan dengan Satuan Hemolitik unit (HU), yang dihasilkan pada beberapa suhu dapat dilihat pada Tabel 1.

Aktivitas hemolitik meningkat seiring dengan peningkatan suhu. Nilai aktivitas optimum berada pada suhu $50^{\circ} \mathrm{C}$ dengan nilai aktivitas hemolitik yaitu 1, $37 \mathrm{HU}$. Pemanasan hingga $50^{\circ} \mathrm{C}$ menyebabkan protein lain selain hemolisin menjadi tidak/kurang aktif sehingga hemolisin dapat

bekerja secara optimal. Namun, pemanasan di atas $50^{\circ} \mathrm{C}$ menyebabkan aktivitas hemolitik menurun akibat hemolisin tidak/kurang aktif. Hasil uji 
pengaruh suhu terhadap aktivitas hemolitik disajikan pada Gambar 1.

Tabel 1. Nilai Aktivitas Hemolitik B.graeffei pada beberapa Suhu

\begin{tabular}{cc}
\hline Suhu $\left({ }^{\circ} \mathbf{C}\right)$ & $\begin{array}{c}\text { Aktivitas Hemolitik } \\
(\text { HU)* }\end{array}$ \\
\hline 25 & 0,98 \\
30 & 0,92 \\
40 & 1,24 \\
50 & 1,37 \\
60 & 0,99 \\
70 & 0,86 \\
80 & 0,66 \\
\hline
\end{tabular}

Keterangan: * Konsentrasi ekstrak kasar $56 \mu \mathrm{g} / \mathrm{ml}$

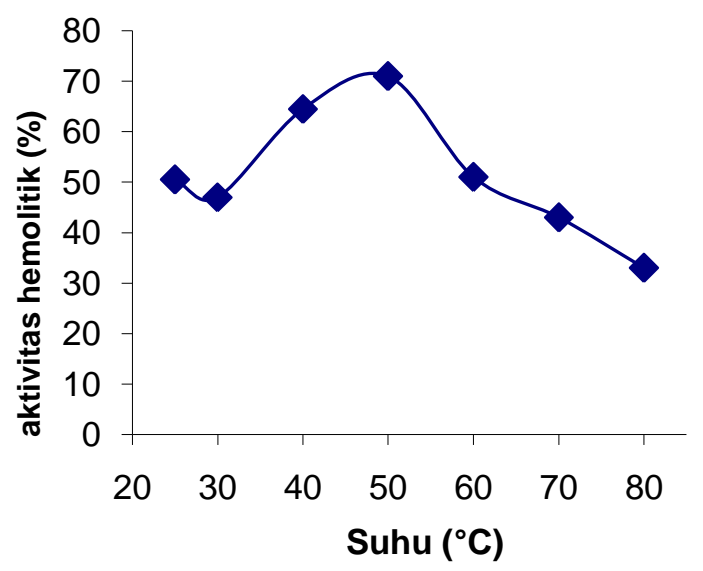

Gambar 1. Persentase aktivitas hemolitik B.graeffei pada beberapa suhu

Martin et al.(1985) menyatakan bahwa kenaikan kecepatan reaksi di bawah suhu optimum disebabkan oleh peningkatan energi kinetik molekul-molekul yang bereaksi. Apabila suhu tetap ditingkatkan hingga melampaui suhu optimum maka energi kinetik molekul-molekul yang bereaksi menjadi sedemikian besar sehingga melampaui penghalang energi untuk pemecahan ikatan-ikatan sekunder. Hal ini akan mengakibatkan protein/enzim kehilangan struktur sekunder dan tersier disertai kehilangan kemampuan hemolitiknya.

Shiomi et al. (1986) melaporkan bahwa hemolisin yang terdapat pada anemon laut (Anthopleura japonica) labil terhadap pemanasan. Pengujiannya pada beberapa suhu $\left(40,60,80\right.$ dan $\left.100{ }^{\circ} \mathrm{C}\right)$ menyebabkan aktivitas hemolitik anemon laut menurun secara linear terhadap peningkatan suhu. Penurunan aktivitas yang dilaporkannya secara berturut-turut sebesar 15,90 dan $95 \%$, sedangkan suhu $100^{\circ} \mathrm{C}$ merusakkan seluruh aktivitasnya. Demikian pula, hemolisin ular laut (Tugali gigas) dilaporkan labil pada pengujian panas (Kamiya et al., 1991).

Hemolisin yang diekstraksi dari cairan coelomic teripang (Holothuria polii) terdiri dari dua jenis yaitu hemolisin yang labil dan yang tidak labil terhadap pemanasan (Kamiya et al., 199). Florkin \& Scheer (1969) juga menyatakan hal serupa bahwa, secara umum, saponin tipe holothurin yang dihasilkan teripang tahan terhadap pemanasan.

Hasil pengujian pada beberapa suhu yang diperoleh dapat dihubungkan dengan suhu optimum yang dibutuhkan bagi aktivitas enzim pada sel-sel teripang. Giese (1979) menyatakan bahwa umumnya aktivitas enzim sel-sel organisme di daerah dingin sangat tinggi bagi enzim bakteri termofilik pada suhu rendah, dan bagi enzim organisme daerah sedang suhu optimumnya sedang.

Teripang (B. graeffei) yang digunakan pada pengujian ini hidup pada zona fotik perairan. Zona ini menerima banyak energi cahaya matahari. Jika dihubungkan dengan pernyataan Giese (1979) maka habitat hidup ini dapat mempengaruhi aktivitas enzim selselnya. Diperkirakan, aktivitas enzim sel-sel teripang ini membutuhkan suhu optimum sedang hingga relatif tinggi. Hasil penelitian menunjukkan bahwa hemolisin pada teripang (B.graeffei) cukup tahan terhadap pemanasan.

\section{Pengaruh pH}

Hasil pengujian pada beberapa nilai $\mathrm{pH}$ menampakkan $\mathrm{pH} 8$ adalah $\mathrm{pH}$ optimum bagi aktivitas hemolitik teripang (Gambar 2). Aktivitas hemolitik meningkat seiring dengan peningkatan $\mathrm{pH}$ kemudian menurun kembali. Nilai aktivitas hemolitik pada beberapa $\mathrm{pH}$ dapat dilihat pada Tabel 2.

Hasil penelitian ini lain halnya dengan jenis hemolisin (AJH-2) yang diisolasi dari anemon laut (A.japonica). Hemolisin jenis ini tidak mengalami perubahan aktivitas selama jangka waktu penyimpanan 1 minggu pada suhu $4^{0} \mathrm{C}$ maupun pada suhu $20{ }^{\circ} \mathrm{C}$ selama 6 bulan (Shiomi et al., 1986). 
Tabel 2. Nilai Aktivitas Hemolitik $B$. graeffei pada beberapa $\mathrm{pH}$

\begin{tabular}{|c|c|}
\hline $\begin{array}{c}\text { Derajat } \\
\text { Keasaman } \\
\text { (pH) }\end{array}$ & $\begin{array}{c}\text { Aktivitas Hemolitik } \\
\text { (HU) }\end{array}$ \\
\hline 3 & 0,14 \\
4 & 0,19 \\
5 & 0,18 \\
6 & 0,20 \\
7 & 0,27 \\
8 & 0,61 \\
9 & 0,29 \\
10 & 0,27 \\
\hline
\end{tabular}

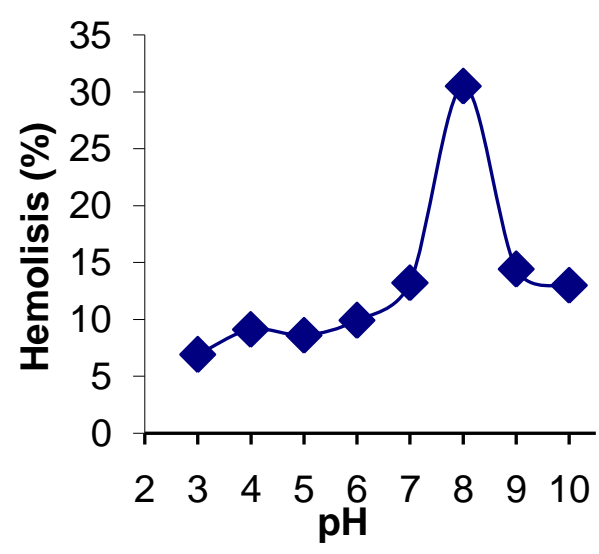

Gambar 2. Persentase aktivitas hemolitik B. graeffei pada beberapa $\mathrm{pH}$

Shiomi et al. (1986) memperoleh dua jenis hemolisin pada anemon laut tersebut. Jenis (AJH-2) yang stabil pada kisaran $\mathrm{pH}$ yang luas ( $\mathrm{pH} 2$ - 11) dan jenis (AJH-1) yang kehilangan $80 \%$ aktivitas hemolitiknya pada $\mathrm{pH}$ 11. Aktivitas hemolitik yang dihasilkan hemolisin ular laut (T.gigas) dinyatakan stabil pada kisaran pH 6 - 9, namun kehilangan aktivitas hemolitiknya pada nilai pH ekstrim (Kamiya et al. 1991).

Pada penelitian ini digunakan $\mathrm{pH}$ yang bervariasi tetapi konsentrasi buffer (dapar) tetap. Kecenderungan meningkatnya kemampuan hemolitik sesuai peningkatan $\mathrm{pH}$ ini dapat dihubungkan dengan pernyataan Martin et al. (1985), jika kecepatan reaksi berubah sebagai fungsi $\mathrm{pH}$ pada konsentrasi buffer tetap maka reaksi dikatakan dikatalisis basa spesifik $(>\mathrm{pH} 7)$ atau asam spesifik ( $<\mathrm{pH} 7)$. Didasarkan pada pernyataan tersebut dapat dikatakan bahwa protein pada hemolisin $B$. graeffei dikatalisis oleh basa spesifik.

\section{KESIMPULAN}

Teripang (B.graeffei) yang diperoleh dari Pantai Malalayang, Sulawesi Utara memiliki aktivitas hemolitik yang tinggi dan berpotensi sebagai sumber hemolisin. Ekstrak kasar hemolisin teripang B.graeffei bekerja optimum pada $50^{\circ} \mathrm{C}$ dan tahan hingga pada suhu $60{ }^{\circ} \mathrm{C}$. Nilai pH optimum aktivitas hemolitik teripang ini berada pada $\mathrm{pH} 8$.

\section{DAFTAR PUSTAKA}

Boorman, K.E., B.E. Dodd \& P.J. Lincoln, 1988. Blood Group Serology, $6^{\text {th }}$ Ed. Churchill Livingstone, New York.

Chalneau N., N. Monina, J. Shin, C. View \& V. Noireaux . 2010. Hemolysin pore formation into a supported phospholipid bilayer using cell-free expression. Elsevier.

Florkin, M \& T. Scheer, 1969. Chemical Zoology. Vol. III. Academic Press, New York.

Giese, A.C. 1979. Cell Physiology. $5^{\text {th }}$ Ed. Topan Comp., Tokyo.

Hashimoto, Y. 1979. Marine Toxins and Other Bioactive Marine Metabolites. Jap. Sci. Soc. Press, Tokyo.

Humm, H.J \& C.E. Lane. 1974. Bioactive Compounds from the Sea. Marcel Dekker, Inc., New York.

Kamiya, H., K. Muramoto \& R. Goto. 1991. Naturally Occuring Hemolysin in the Marine Snail Tugali gigas. Bull. Jap. Soc. Sci. Fish. 57 (11) : p. 2109-2113.

Martin, D.W., P.A. Mayes, D.K. Granner, V.W. Rodwell \& I. Darmawan, 1987. Biokimia. Edisi 20. EGC, Jakarta.

Russsell, F.E. 1965. Marine Toxins and Venomous and Poisonous Marine Animals. Adv. Mar. Bio. Vol. 3. p. 255-384.

Shiomi, K., M. Takamiya, H. Yamanaka \& T. Kikuchi, 1986. Physicochemical Properties of a Lethal Hemolysin Isolated from Sea Anemon Anthopleura japonica. Bull. Jap. Soc. Sci. Fish. 52 (3) : p. 539-543. 
Tiensongrusmee, B \& S. Pontjoprawiro. 1988. Budidaya Teripang, Potensi dan Prospeknya. Seafarming Dev. Proj. FAO/UNDP, Jakarta.

Tu, A.T. 1988. Marine Toxins and Venoms. Handbook of Natural Toxins. Vol. 3. Marcel Dekker, Inc., USA.
Wright, J.L.C.1984. Biologically Active Marine Metabolites: Some Recent Examples. Proc. N. S. Inst. Sci. 34:p. 131-161. 